the statistical analysis. We are also grateful to the Victor Hurley Research Fund of the Royal Melbourne Hospital for support and to Mrs. K. Myles and Miss J. Gray for expert technical help.

\section{References}

Alford, F. P., Martin, F. I. R., and Pearson, M. J. (1971). Diabetologia, 7, 173. Britt, B. A., and Kalow, W. (1970). Canadian Anaesthetists' Society fournal, 17,316 .
Denborough, M. A., et al. (1973). In International Symposium on Malignant Hyperthermia, ed. A. Gordon, B. A. Britt, and W. Kalow, p. 229. Springfield, Illinois, Thomas.

Huff, T. A., Horton, E. S., and Lebovitz, H. E. (1967). New England fournal of Medicine, 277, 837

Kagan, A., Brunner, N. G., and Grob, D. (1969). Clinical Research, 17, 286. Malaisse, W. J. (1973). Diabetologia, 9, 167.

Malaisse, W. J., and Malaisse-Lagae, F. (1970). Acta Diabetologica Latina, 7, Suppl. No. 1, p. 264

Moulds, R. F. W., and Denborough, M. A. (1974). British Medical fournal,

Snedecor, G. W., and Cochran, W. G. (1967). Statistical Methods, 6th edn., p. 114. Ames, Iowa State University Press.

\title{
Familial Clustering of Hepatitis B Antigen: A Study in Relatives of Patients with Liver Diseases and Hepatitis B Antigenaemia
}

\author{
MIGUEL BRUGUERA， JAIME BOSCH， JUAN RODÉS， JOSE PEDREIRA
}

British Medical fournal, 1974, 3, 495-497

\section{Summary}

Twelve of the 100 family contacts of 29 patients with transient and persistent hepatitis $B$ antigenaemia were found to be positive for hepatitis $B$ antigen (HBAg). No relation was found between familial clustering and the nature of liver disease or the duration of antigenaemia in the index cases.

Eight affected relatives were apparently healthy carriers of HBAG, one had cirrhosis, and three (in the same family) developed acute viral hepatitis.

The absence of parenteral exposure in the HBA,-positive family contacts and the identity in antigenic determinants $d$ or $y$ with those of the index cases, suggest a nonparenteral spread of $\mathrm{HBAg}$ in families of patients with HBAg-associated liver diseases.

\section{Introduction}

Nonparenteral transmission of viral hepatitis type B has been reported by several investigators (Krugman et al., 1967; Koff and Isselbacher, 1968; Giles et al., 1969). Krugman and Giles (1970) showed that long-incubation hepatitis could be transmitted orally under controlled conditions, and some reports have suggested other noutes of transmission such as airborne (Almeida et al., 1971; Garibaldi et al., 1972), venereal (Hersh et al., 1971; Fulford et al., 1973; Heathcote and Sherlock, 1973; Jeffries et al., 1973), and transplacental (Schweitzer et al., 1973). In most cases of hepatitis B without parenteral exposure, however, the exact mode of transmission of the disease cannot be determined.

The familial clustering of carriers of hepatitis $B$ antigen (HBAg) provides epidemiologic evidence of nonparenteral

Liver Unit, University of Barcelona, Hospital Clinico y Provincial Barcelona, Spain

MIGUEL BRUGUERA, M.D., Physician

JAIME BOSCH, M.D., Physician

JUAN RODES, M.D., Director of the Liver Unit

Department of Medicine, University Autonoma of Barcelona, Ciudad Sanitaria de la Seguridad Social, Barcelona, Spain JOSE PEDREIRA, M.D., Physician spread of the hepatitis virus B. Szmuness et al. (1973) and Berris et al. (1973) have shown that the spread of hepatitis B infections among relatives of asymptomatic blood-donor carriers is considerable, but the incidence of familial clustering among relatives of patients with acute and chronic liver diseases with hepatitis $B$ antigenaemia has not yet been assessed.

We report here the findings of a survey done to evaluate the incidence of HBAg in family units of Spanish patients with $\mathrm{HBAg}$-positive liver diseases.

\section{Patients and Methods}

The series included 100 of the 108 household relatives of 29 partients, (index cases) with HBAg-positive liver diseases (12 acute viral hepatitis, nine chnonic hepatitis, and eight cirhosis) admitted to the liver unit of the Hospital Clinico y Provincial, Barcelona.

Screening for HBAg was carried out by countercurrent electrophoresis (Pesendorfer et al., 1970). Subtyping was performed by two-dimensional agar gel diffusion (Prince, 1968) using human monospecific ad and ay antiserums. These antiserums showed identity lines against reference antigens from Y. Cossart, Virus Reference Laboratory, London. Transaminase activity was determined by the kinetic spectrophotometric method (Wroblewski and La Due, 1956).

A personal interview was held in all cases to exclude other possible sources of exposure to the hepatitis B virus-for example, blood transfusions, injections with a shared needle, vaccinations, surgical or dental procedures, tattooing, or contact with cases of hepatitis other than the affected relatives.

\section{Results}

Twelve of the 100 relatives investigated were found to be antigen carriers. Clustering of HBAg occurred in nine $(31 \%)$ of the 29 families. The number of contacts in these nine families was 39, showing a prevalence of $\mathrm{HBAg}$ of $31 \%$.

No relation was found between the nature of liver disease in the index cases and the presence of hepatitis B antigenaemia in the relatives (table $I$ ). The frequency of detection of HBAg varied between specific relatives of the index cases (table II). The highest incidence was among offspring though it was not significantly different from that found in spouses. Non-blood relatives other than spouses did not present $\mathrm{HBAg}$ in the serum. 
TABLE I-Relation between Liver Disease in Index Cases and Familial Clustering of $H B A g$-positive Contacts

\begin{tabular}{l|c|c}
\hline \multicolumn{1}{c|}{ Disease } & No. of Index Cases & $\begin{array}{c}\text { No. of Families with } \\
\text { HBAg-positive Members }\end{array}$ \\
\hline Viral Hepatitis & 12 & 3 \\
Chronic hepatitis & 9 & 3 \\
Cirrhosis & 8 & 3
\end{tabular}

TABLE II-Incidence of HBAg in Family Contacts

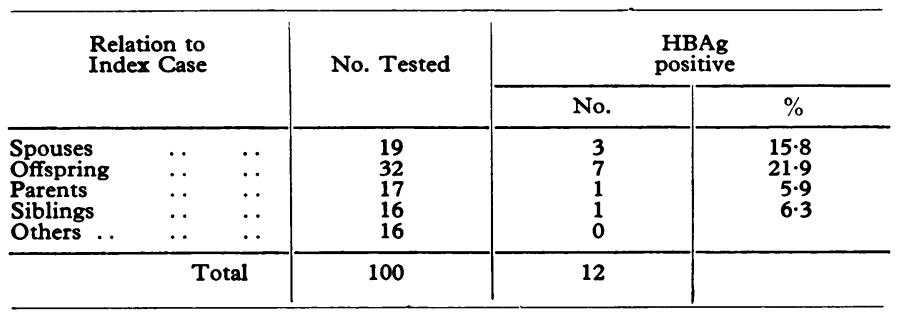

Eight of the affected relatives showed no clinical or biochemical signs of liver disease and were considered to be healthy carriers of the hepatitis $B$ virus though liver biopsies were not performed. They remained $\mathrm{HBAg}$ positive when tested again four to six months later. The features of these $\mathrm{HBAg}$-positive relatives are shown in table III.

TABLE III-Data on $12 \mathrm{HBAg}$-positive family contacts

\begin{tabular}{|c|c|c|c|c|c|}
\hline $\begin{array}{l}\text { Case } \\
\text { No. }\end{array}$ & Age & Sex & $\begin{array}{l}\text { Relation to } \\
\text { Index Case }\end{array}$ & Liver disease & $\begin{array}{l}\text { Relation to other } \\
\text { HBAg-positive } \\
\text { Contacts }\end{array}$ \\
\hline $\begin{array}{l}1 \\
2 \\
3 \\
4 \\
5 \\
6 \\
7 \\
8 \\
9\end{array}$ & $\begin{array}{r}20 \\
14 \\
8 \\
16 \\
7 \\
8 \\
25 \\
23 \\
46\end{array}$ & $\begin{array}{l}\text { M. } \\
\text { M. } \\
\text { F. } \\
\text { F. } \\
\text { F. } \\
\text { F. } \\
\text { M. } \\
\text { F. } \\
\text { M. }\end{array}$ & $\begin{array}{l}\text { Son } \\
\text { Son } \\
\text { Daughter } \\
\text { Daughter } \\
\text { Daughter } \\
\text { Sister } \\
\text { Husband } \\
\text { Wife } \\
\text { Husband }\end{array}$ & Viral hepatitis & $\begin{array}{l}\text { Brother of case } 2 \\
\text { Brother of case } 1\end{array}$ \\
\hline $\begin{array}{l}10 \\
11 \\
12\end{array}$ & $\begin{array}{r}21 \\
3 \\
64\end{array}$ & $\begin{array}{l}\text { F. } \\
\text { M. }\end{array}$ & $\begin{array}{l}\text { Daughter } \\
\text { Daughter } \\
\text { Father }\end{array}$ & $\begin{array}{l}\text { Viral hepatitis } \\
\text { Viral hepatitis } \\
\text { Cirrhosis }\end{array}$ & $\begin{array}{l}\text { Daughter of case } 9 \\
\text { Daughter of case } 9\end{array}$ \\
\hline
\end{tabular}

In one family there was an outbreak of acute type B hepatitis. The index case was a 43-year-old woman admitted because of jaundice. The diagnosis of viral hepatitis was based on biochemical findings, liver biopsy, and the fact that she was positive for HBAg. She had had no parenteral exposure, but her 13-year-old daughter had been admitted to another hospital two months earlier with acute hepatitis appearing after repeated injections with nondisposable syringes. Family contacts were examined two months later. They had no complaints, but her two daughters aged 21 and 3 (cases 10 and 11) were found to be HBAg positive and to have raised levels of serum transaminases. The husband (case 9), who had been found normal, developed jaundice 58 days after the first examination; he had raised levels of serum transaminases and was positive for HBAg. By this time the mother and her two daughters (cases 10 and 11) were negative for antigen and and serum transaminase levels were normal. Except for the 13-year-old girl no parenteral exposure was elicited in the remaining cases.

In another family there were two members with chronic liver disease. The index case was a 35-year-old man admitted for investigation of persistently raised levels of serum transaminases. He was positive for $\mathrm{HBAg}$, and a liver biopsy showed chronic aggressive hepatitis. Examination of the household disclosed that his father (case 12) was HBAg positive and had abnormal liver function test results. Liver biopsy showed cirrhosis.

Sera from all positive members of four families (10 cases) were suitable for HBAg subtyping by agar gel diffusion. A concordance in the antigenic determinants of HBAg was found in each family. Members of two families had subtype ad and those of the two other families had subtype ay. There was no relation between either of these determinants and the nature of liver disease in the index cases and in the positive households.

\section{Discussion}

Szmuness et al. (1973) and Berris et al. (1973) found a high prevalence of carriers of HBAg in relatives of blood donors with chronic antigenaemia. This study shows similar findings among the relatives of patients with acute and chronic liver diseases associated with hepatitis $B$ antigenaemia. The incidence of HBAg in their household contacts (12\%) contrasts sharply with the prevalence of the antigen in hospital patients without liver disease $(0.3 \%)$ and in unpaid blood donors $(0.4 \%)$ in the same geographic area (Bosch et al., 1973)

The nature of our study rules out any consideration of whether index cases in families with clustering of HBAg positive members were actually primary cases or whether they acquired the disease as a consequence of close contact with an asymptomatic chronic carrier. No history of parenteral exposure was obtained from any of the relatives who were found to be HBAg positive. Thus a nonparenteral route of transmission could be involved, favoured by close and long-term contact with an infected person. The finding of the same subtype $d$ or $y$ in all the positive cases of each family seems to support this theory. Nevertheless, parenteral transmission can never be entirely excluded, given the fact that within households several articles such as razors, combs, nail scissors, and cutlery are often shared and may provoke an unapparent parenteral inoculation.

Two main routes of nonparenteral spread of hepatitis B virus have been suggested; airborne and venereal. Almeida et al. (1971) and Garibaldi et al. (1972) have reported two outbreaks of acute type B hepatitis in subjects who were present when blood from two patients with hepatitis B antigenaemia submitted to haemodialysis was accidentally spilt. The simultaneous onset of the hepatitis and the absence of a direct contact with the blood in some of the cases would suggest airborne transmission of the virus through aerosols of contaminated blood. Hersh et al. (1971) described eight women in whom hepatitis B was apparently transmitted from their husbands or other sexual partners positive for $\mathrm{HBAg}$. Recently Heathcote and Sherlock (1973), Fulford et al. (1973), and Jeffries et al. (1973) have reported epidemiologic data suggesting sexual transmission of hepatitis B, particularly among homosexuals. Investigations into the presence of $\mathrm{HBAg}$ in faeces and urine have produced conflicting results (Grob and Jemelka, 1971; Gust et al., 1971; Heathcote et al., 1973), but the antigen has been found in saliva and semen (Heathcote et al., 1974), and it may be present in the menstrual discharge of women carrying the antigen (Mazzur, 1973).

It has not been established whether these routes of nonparenteral spread have any role in the high incidence of $\mathrm{HBAg}^{\circ}$ in sporadic urban hepatitis (Cossart and Vahrman, 1970; Bruguera et al., 1973), but they do not cover the findings of the present survey. In none of the nine families with clustering of HBAg positive individuals could a history of exposure to contaminated blood be traced, and only in three cases was the antigen found in spouses of the index cases. Szmuness et al. (1973) detected a high incidence of antibody to HBAg in spouses of the blood-donor carriers, suggesting a possible transmission of the virus by sexual intercourse. They discovered, however, as did Berris et al. (1973), a higher incidence of asymptomatic carriers of the antigen among blood relatives than in spouses. This finding might support the hypothesis of a genetic predisposition to the $\mathrm{HBAg}$ carrier 
state (Blumberg et al., 1969). The small number of patients investigated in the present survey, which included only the relatives living in the patients' homes and the fact that we included cases with transient antigenaemia precludes any consideration of this hypothesis. On the other hand, most carriers were children or young people, which supports the observations of Szmuness and Prince (1971), who stressed the importance of an "age factor." They showed that the risk of becoming a chronic carrier is significantly increased if exposure to the HBAg occurs at an early age.

The detection of chronic carriers of HBAg among household relatives of subjects with persistent antigenaemia would suggest that person-to-person transmission needs a close and long-term contact with the virus reservoir, this being unlikely among contacts of subjects with transient antigenaemia. Dietzman et al. (1973) found no evidence of familial spread of HBAg in relatives of six drug addicts who had acute type B hepatitis. An outbreak of hepatitis B was observed in one family included in our survey, however, indicating that in certain conditions liver diseases associated with transient antigenaemia may be source of nonparenteral spread of virus hepatitis.

Our data suggest that relatives of patients with $\mathrm{HBAg}$ positive liver disease are much more likely .0 be carriers of the antigen than the general population is. Investigation of these contacts is worthwhile since it may disclose cases of otherwise unsuspected acute and chronic liver disease as well as healthy carriers of the antigen, whose identification is important in order to limit the spread of hepatitis virus B.
Requests for reprints should be sent to Dr. M. Bruguera.

\section{References}

Almeida J., et al. (1971). Lancet, 2, 849.

Berris, B., et al. (1973). Annals of Internal Medicine, 79, 690

Blumberg, B. S., Friedlaender, J. S., and Woodside, A. (1969). Proceedings of the National Academy of Sciences of the United States of America, 62, 1108.

Bosch, J., Bruguera M., and Rodés J. (1973). Lancet, 2, 457.

Bruguera M., Rodes J., and Terés J. (1973). Medicina Clinica, 61, 65.

Cossart Y., and Vahrman J. (1970). British Medical fournal, 1, 403.

Dietzman D. E., et al. (1973). New England fournal of Medicine, 289, 1409 Fulford, K. W. M., et al. (1973). Lancet, 1, 1470.

Garibaldi R. A., et al. (1972). Fournal of American Medical Association, 220, 1963.

Giles, J., et al. (1969). New English Fournal of Medicine, 218, 119.

Grob, J. J., and Jemelka H. (1971). Lancet, 1, 206.

Gust, I. D., Kaldor, J., and Nastasi, M. (1971). Lancet, 1, 797.

Heathcote, J., and Sherlock, S. (1973). Lancet, 1, 1468.

Heathcote, J., and Sherlock, S. (1973). Lancet, 1, 1468.

Heathcote, J., Tsianides A., and Sherlock S. (1973). Lancet, 2, 593.

Hersh, T., et al. (1971). New England fournal of Medicine, 285, 1363.

Jeffries, D. J., et al. (1973). British Medical fournal, 2, 455.

Koff R. S., and Isselbacher, K. J. (1968). New England fournal of Medicine, 278, 1371 .

Krugman S., Giles, J. P., and Hammond, J. (1967). Fournal of American Medical Association, 200, 365.

Krugman S., and Giles, J. P. (1970). Fournal of American Medical Association, 212, 1019.

Mazzur S. (1973). Lancet, 1, 749.

Pesendorfer F., Kassnitaky, D., and Wewalka F. (1970). Vox Sanguinis, 19, 200.

Schweitzer J. L. et al. (1973). Gastroenterology, 65, 277.

Szmuness, W., and Prince, A. M. (1971). American fournal of Epidemiology, 94, 585.

Szmuness W., et al. (1973). New England fournal of Medicine, 290, 1162.

Wroblewski, F., and la Due J. S. (1956). Proceedings of the Society of Ex-: perimental Biology and Medicine, 91, 569.

\title{
An Outbreak of Streptococcal Skin Sepsis in a Closed Community
}

\author{
C. I. BACKHOUSE, R. Y. CARTWRIGHT
}

British Medical fournal, 1974, 3, 497-499

\section{Summary}

An outbreak of skin sepsis due to $\beta$-haemolytic streptococcus group A M33, T3/13/B3264 occurred in a closed community. Staphylococcus aureus was also present in many of the lesions, but different strains were recognizable by phage typing. Environmental contamination was found. The outbreak was controlled by isolating infected boys and decontaminating the environment. Various aspects of the epidemiology and the pathogenesis of streptococcal infections are discussed.

\section{Introduction}

The $\beta$-haemolytic streptococcus Lancefields group A, Streptococcus pyogenes, was described by Rosenbach in 1884. The two most common sites of streptococcal infection in man are the upper respiratory tract and the skin. The importance of skin

\footnotetext{
General Practice

C. I. BACKHOUSE, M.B., D.oBst.R.c.o.G., Medical Officer, H.M. Prison Service

Public Health Laboratory, St. Luke's Hospital, Guildford, Surrey GU1 3NT

R. Y. CARTWRIGHT, M.B., M.R.C.PATH., Consultant Microbiologist
}

infections, particularly impetigo, has been more fully recognized during the past decade, and differences in the clinical appearances, epidemiology, and pathogenesis of streptococcal infections of skin and pharynx have been reviewed by Wannamaker (1970).

Rammelkamp et al. (1958) produced some evidence that the drying of oropharyngeal secretions reduced their infectivity and concluded that contaminated dust played only a minor role in the spread of streptococcal infections of the upper respiratory tract. They suggested, however, that in favourable conditions skin infections would occur. In the outbreak described here there were no streptococcal sore throats, and skin infection resulted from abrasions sustained mainly in the gymnasium, where heavy environmental contamination with the epidemic strain could be shown.

Epidemics of acute glomerulonephritis associated with skin infection have occurred in Trinidad (Simon et al., 1965) and at the Red Lake Indian Reservation, Minnesota (Kleinman, 1954; Anthony et al., 1967). Investigators of these epidemics have reported previously unrecognized nephritogenic strains of group A streptococci. The relation between impetigo and acute glomerulonephritis is reviewed by Dillon (1972).

\section{The Outbreak}

The outbreak occurred among boys in a detention centre in the South of England. The centre held an average of 100 boys aged 17-20, who usually remained for eight weeks though a few stayed for longer periods. On arrival they slept in single-bed cubicles in dormitory $\mathrm{A}$. They then progressed through open 